\title{
Quantitative evaluation of a subject-specific essay-writing intervention
}

\author{
Adelia Carstens ${ }^{1 *}$ and Lizelle Fletcher ${ }^{2}$ \\ 1 Unit for Academic Literacy, University of Pretoria, Pretoria 0002, South Africa \\ ${ }^{2}$ Department of Statistics, University of Pretoria, Pretoria 0002, South Africa \\ *Corresponding author, e-mail: adelia.carstens@up.ac.za
}

\begin{abstract}
Discipline- and genre-specific approaches in language teaching have gained much support in recent years. However, few studies have thus far evaluated the effect of courses resulting from narrow-angled approaches. This article reports on the evaluation of a 14-week essay-writing module for second-year students of history. The aim of the evaluation was to measure the effect of the intervention both through analytic scoring of pre- and post-test essays, and gauging students' opinions by means of a survey at the conclusion of the module. The main finding, supported by statistical analyses, was that students' writing abilities improved significantly between the preand the post-test. The overall improvement was roughly equal on the three primary dimensions measured by the analytic assessment tool: 'Handling of source materials' (18\%), 'Structure and development' (18\%) and 'Language and style' (19\%). According to an attitude survey conducted at the conclusion of the intervention students were generally positive about the effect of the intervention on their academic writing abilities. They showed appreciation for all the 'signature' features of a genre-focused approach, and their responses seem to refute the criticism that genre approaches promote transmission pedagogy.
\end{abstract}

\section{Introduction}

The 'common-core' versus 'subject-specific' issue in language pedagogy has been debated for at least 20 years. Proponents of the subject-specific approach include scholars such as Faigley and Hansen (1985), Biber (1988; 2006), Tedick (1990), Berkenkotter and Huckin (1995), Hyland (2000; 2003; 2004; 2006) and Hewings and Hewings (2001). These academics argue that genres are not merely formally linked to disciplines; they are intimately linked to a discipline's methodology, and they package information in ways that conform to a discipline's norms, values and ideology. Berkenkotter and Huckin (1995) are convinced that the extent to which English second-language writers are familiar with subject matter has a dramatic influence on their writing performance.

A number of studies conducted by genre analysts have emphasised the systematic relationship between disciplinary purposes, genre and register (compare Bhatia, 2004; Hyland, 2000; Jones, 2004; Hewings, 2004; Hyland \& Bondi, 2007) and the positive effects of genre-specific and discipline-specific approaches. However, few studies have thus far given a systematic account of form-function relationships in specific disciplines, used such information as input for course design, or evaluated the effect of such courses. This article reports on a project that was undertaken to produce primarily quantitative evidence of the effectiveness of a genre-focused and subject-specific writing intervention.

First, background to the evaluation project is provided, comprising an overview of the contextual research that was conducted to inform and justify the syllabus for the writing intervention. Thereafter an outline of the syllabus is presented. The remainder of the article offers a comprehensive description of the evaluation process, including research methods, findings, conclusions and limitations.

\section{Background}

During 2007 a survey of writing tasks required by academic disciplines in the Faculty of Humanities was conducted at the University of Pretoria (Carstens, 2008a). Study guides from a representative sample of departments were collected, and all tasks requiring extensive writing were excerpted 
and analysed to establish the genres they belonged to as well as the text types (modes of writing) they demanded. The academic essay was found to be the genre with the highest frequency, and the materials of the Department of Historical and Heritage Studies contained the highest number of essay-length tasks: 88 of all the assignments included in study guides of the Department of Historical and Heritage Studies belonged to the essay genre. These findings constituted the rationale for the decision to design and evaluate a writing intervention for students of history. The decision was further supported by the fact that history is a subject field which exists purely by virtue of language (Schleppegrell et al., 2004). It was decided to focus the intervention on second-year students because intermediate-level undergraduates should have developed some awareness of academic writing abilities, and thus also their educational needs.

Following the advice of Bhatia (1993; 2004) and Hyland (2000) on conducting research for the implementation of a genre-based syllabus, recently published manuals on writing about history (compare Rael, 2004; Rampolla; 2004; Storey, 2004; Marius \& Page, 2005) were studied in addition to conducting expert reviews that would bring an insider perspective to the analysis. Four senior staff members from the Department of Historical and Heritage Studies were approached to perform an expert review on a document the first author had written on the relationship between disciplinary purposes and writing conventions in the field of history. From their responses it was clear that style guides and writing manuals - even those written by historians - tend to present the conventions of the discourse community in a rather simplistic and often prescriptive way. The experts advised consultation of scholarly sources on historical writing to facilitate a more balanced perspective. The recommended sources included scholarly overviews of trends in historical writing from different historical periods and ideological perspectives (Shafer, 1980; Evans, 1997; Burke, 2001; Marwick, 2001; Sharpe, 2001; Tosh, 2006), as well as overviews of South African history in particular (Smith, 1988; Saunders, 1988). The expert review led to a thorough revision of the first author's initial understanding of form-function relationships in historical discourse, and suggested additional ways to investigate the nature of historical writing. A comprehensive description of this contextual research is found in Carstens (2008c).

In addition to the research on the purposes of historians, and the linguistic correlates of these purposes, a thorough literature review was conducted on syllabus design for subject-specific writing, with specific reference to history (compare Cope \& Kalantzis, 1993; 2000; Eggins et al., 1993; Rothery, 1996; Macken-Horarik, 2002; Coffin 2003; 2006; Martin 2003; Schleppegrell \& Achugar, 2003; Schleppegrell et al., 2004). Carstens (2008c) provides a detailed account of the pivotal concepts which students of history have to master: time, cause and effect and judgment, and the linguistic resources needed to construe these concepts in ways that are acceptable to expert members of the discourse community. The syllabus that resulted from the contextual research is expounded in Table 1.

From a pedagogical perspective the syllabus was framed upon the Teaching and Learning Cycle of the Australian genre school. The cycle comprises an exploration of texts (deconstruction), followed by joint construction of texts by the teacher and the class, independent construction of texts, and critical reflection on the basis of self-, peer and teacher evaluation (compare Cope \& Kalantzis, 1993: 2000). The phases may be applied recursively. Theoretically, the cycle combines Halliday's view of what is involved in language learning (learning language, learning through language and learning about language - Halliday, 1978) with Vygotsky's (1978) ideas about learning as a collaborative and scaffolded social activity into a principled sequence of language teaching activities. The history writing syllabus was further hybridised in a considered way by integrating elements from other 'discourses' in language pedagogy, such as the process approach and elements of critical literacy approaches (Weideman, 2007; Carstens, 2008b).

\section{Assessment and quantitative data analysis}

\section{Method}

Sixteen students with history as a major subject in their second year of study self-selected to register non-formally for a semester course on essay writing after having been informed about the course in one of their history classes. Eventually ten students completed the course: one mother-tongue 
Table 1: Syllabus for a module on essay writing for students of history

Study unit theme

Study unit 1

Introduction to historical discourse
Syllabus themes

Why study history and why write about it?

Different perspectives to writing history (critical exploration of texts from the main traditions: Rankean [19th century) history, New History, Marxism, postmodernism)

\section{Study unit 2}

Exploring preferred modes of writing in historical discourse
Identifying parts of texts with different functions:
Giving an overview/summarising
Telling a story/describing an event
Describing an object or an experience
Comparing and contrasting
Indicating and describing causes and effects
Arguing a case

Analysing and interpreting writing prompts

Selecting appropriate modes for assignments

Writing short texts using a particular mode
Study unit 4
Getting acquainted with history essays
The three-part structure of academic essays

(Optional) subsections

Three main essay genres in history and their prototypical structures: recording, explaining, judging and interpreting Important stylistic, lexical and grammatical dimensions: time, causality, evaluation and abstractness

Jointly analysing writing prompts in terms of required content, structure and language

Brainstorming and planning content

Jointly composing subsections of essays

Revising

Critiquing the essay and reflecting on the process
Study unit 6

Writing your own history essay
Independent composition of a first and second draft, with peer and teacher feedback as well as personal reflection.

Afrikaans speaker, one mother-tongue English speaker (of Indian descent) and eight speakers of African languages. The six who had fallen off the course were contacted by the researcher, and the following reasons were given for their discontinuation of the module: Two students quit immediately after the pre-test when they realised that the module was not credit-bearing; two indicated that the essay-writing module clashed with a core subject on one of the weekly contact sessions; one student, who obtained a high distinction in the pre-test, argued that the possible gains did not weigh up against the amount of work required for the module; and one decided to discontinue the essaywriting module after seven weeks when realising that she had overcommitted.

The 14-week intervention (consisting of two contact sessions per week) commenced in July 2008. A part-time lecturer in the Unit of Academic Literacy with English as a major and a master's degree in History was recruited to teach the course. She was remunerated from the first author's research account. Course materials consisted of a 50-page study guide based on the syllabus, a reader comprising a selection of scholarly articles and chapters from books on historical subjects, the Study Manual of the Department of Historical and Heritage Studies (2006), and a number of model essays.

All students who took part in the project received the intervention along with a pre-test and a post-test. The participants signed a letter of consent at the beginning of the course to allow the use their essays and their survey responses for research purposes. The pre-test assumed the format of a 50-minute in-class essay during the second week of the module, on a topic related to the content of the second-year history curriculum, viz.: 'Discuss black reaction and resistance to the Natives Land Act of 1913.' Students were required to study source materials from the reader during the 
preceding week, and were allowed to use the reader as an in-class resource. The conditions for the post-test were exactly the same as for the pretest, only the topic differed: 'Discuss how segregation affected the social and economic situation of black South Africans.'

The assessment instrument was a scoring rubric comprising 15 items. The values were defined as percentage ranges to assist the assessors in conceptualising each mark in terms of a benchmark that would resonate with generally conceived achievement levels:

\begin{tabular}{ccccccc}
\hline $7=85-100 \%$ & $6=75-84 \%$ & $5=65-74 \%$ & $4=50-64 \%$ & $3=36-49 \%$ & $2=26-35 \%$ & $1=0-25 \%$ \\
Excellent & Very good & Good & Average & Below average & $\begin{array}{c}\text { Poor } \\
\text { Very poor }\end{array}$ \\
\hline
\end{tabular}

An N/A option was included for items that might not be relevant for a particular assessment.

Seven-point scales were used for 14 of the items, while the 15th had to be rated on a two-point scale. The rationale for rating 'Legibility and layout' on a two-point scale was to obtain a cumulative score of 100. Items 16 and 17, the 'Total' and the 'Overall percentage', were only numbered for statistical purposes. Items 1-15 were clustered into four dimensions: 'Use of source material', 'Structure and development', 'Academic writing style', and 'Editing'. Three empirically based and internationally accredited analytic rating scales contributed input for the instrument: the TOEFL writing scoring guide; the Scoring profile of Jacobs et al. (1981) (cited by Weigle, 2002); and the Masus rating sheet of Bonanno and Jones (2007). The scale was not intended to be overtly genre-based, because the purpose of the intervention was not to teach students a particular pedagogical approach, but to assist them in learning how to write academic essays. Table 2 is a reproduction of the scoring instrument.

Prior to the intervention the instrument was piloted on 12 in-class test essays on the topic of 'How Lenin and his Bolshevik government managed to remain in power from 1917 to 1924 despite numerous setbacks', which had been obtained from the Department of Historical and Heritage Studies. Adjustments were made on the basis of the relative ease and/or difficulty of use of the rating instrument, and the general agreement between the results of the analytic scoring and an impression mark. It was decided to use the N/A option for item 14, 'Referencing technique', since referencing is normally not required for timed in-class essays; and also for item 15, 'Legibility and layout', since design features cannot easily be adapted in a single draft timed essay (as opposed to a multiple draft homework essay).

After the pre-test essays had been written they were scored independently by the course designer (Rater 1) and the class lecturer (Rater 2), using the adapted rubric. The same rubric was used for the post-test. Unfortunately, fairly large discrepancies occured between the scores of the two raters, regarding both the pre-test and the post-test. On average the pre-tests were scored $7.1 \%$ lower by Rater 2 than by Rater 1 . The converse was true for the post-tests, which were on average scored $6.6 \%$ higher by Rater 2 than by Rater 1 . Possible explanations for the discrepancies are: (1) the two raters focused on different aspects of essay quality - content in the case of Rater 2, and form in the case of Rater 1; (2) Rater 2 had ample experience in rating history essays, but less experience in assessing academic writing, whereas Rater 1 had 25 years of experience in the assessment of writing; and (3) Rater 2's scores might have subconsciously been influenced by a desire to prove the effectiveness of the intervention.

Because of the large discrepancy between the two raters' scores, and the possibility that the differences between the pre- and post-test scores would be inflated if the average of the two raters' scores were used, the authors jointly decided to use only Rater 1's scores.

\section{Presentation and discussion of students' results}

The total score for each of the ten respondents was converted to a percentage for ease of interpretation (compare Figure 1).

The average improvement of the ten respondents was $19 \%$. Nine respondents performed better on the post-test than on the pre-test. The single student who performed worse on the post-test, did so by a mere two per cent.

Figure 2 displays the average results per item after conversion to percentages. 
Table 2: Analytical scoring rubric for the assessment of academic essays

\begin{tabular}{|c|c|c|c|c|c|c|c|c|}
\hline Use of source material & & & & & & & & \\
\hline 1. Relevance of source data & 7 & 6 & 5 & 4 & 3 & 2 & 1 & $\mathrm{~N} / \mathrm{A}$ \\
\hline 2. Integration of source data with text & 7 & 6 & 5 & 4 & 3 & 2 & 1 & N/A \\
\hline 3. Stance and engagement & 7 & 6 & 5 & 4 & 3 & 2 & 1 & $\mathrm{~N} / \mathrm{A}$ \\
\hline \multicolumn{9}{|l|}{ Structure and development } \\
\hline 4. Thesis statement: clarity and focus & 7 & 6 & 5 & 4 & 3 & 2 & 1 & $\mathrm{~N} / \mathrm{A}$ \\
\hline 5. Development of main argument & 7 & 6 & 5 & 4 & 3 & 2 & 1 & $\mathrm{~N} / \mathrm{A}$ \\
\hline 6. Conclusion & 7 & 6 & 5 & 4 & 3 & 2 & 1 & $\mathrm{~N} / \mathrm{A}$ \\
\hline 7. Paragraph development & 7 & 6 & 5 & 4 & 3 & 2 & 1 & $\mathrm{~N} / \mathrm{A}$ \\
\hline \multicolumn{9}{|l|}{ Academic writing style } \\
\hline $\begin{array}{l}\text { 8. Syntax: phrase and clause structure, sentence } \\
\text { length }\end{array}$ & 7 & 6 & 5 & 4 & 3 & 2 & 1 & $\mathrm{~N} / \mathrm{A}$ \\
\hline 9. Concord and tense & 7 & 6 & 5 & 4 & 3 & 2 & 1 & N/A \\
\hline 10. Linking devices & 7 & 6 & 5 & 4 & 3 & 2 & 1 & $\mathrm{~N} / \mathrm{A}$ \\
\hline 11. Technical lexis & 7 & 6 & 5 & 4 & 3 & 2 & 1 & N/A \\
\hline 12. Style (formality; rhetorical mode) & 7 & 6 & 5 & 4 & 3 & 2 & 1 & $\mathrm{~N} / \mathrm{A}$ \\
\hline \multicolumn{9}{|l|}{ Editing } \\
\hline 13. Spelling, capitalisation and punctuation & 7 & 6 & 5 & 4 & 3 & 2 & 1 & $\mathrm{~N} / \mathrm{A}$ \\
\hline 14. Referencing technique & 7 & 6 & 5 & 4 & 3 & 2 & 1 & $\mathrm{~N} / \mathrm{A}$ \\
\hline 15. Legibility and layout & good 2 & & & & poor 0 & & & N/A \\
\hline \multicolumn{9}{|l|}{ 16. Total } \\
\hline 17. Overall percentage & & & & & & & & \\
\hline
\end{tabular}



Figure 1: Comparison of pre- and post-test results per respondent

Per item, all the post-test ratings were higher than the pre-test ratings: On four items the improvement was between $20 \%$ and $26 \%$ (items 1, 7, 8 and 11 ); on six items the improvement was between $15 \%$ and $19 \%$ (items $2,5,6,10,12$ and 13); and on the remaining three items the improvement was between $11 \%$ and $13 \%$.

\section{Statistical analysis}

The Wilcoxon signed-rank test (SPSS V17; Williams et al., 1999; Sweeney \& Anderson, 2009) was used to assess if the differences between the pre- and post-test ratings on each of the 13 questions comprising the instrument were significant. The Wilcoxon signed-rank test is a non-parametric 


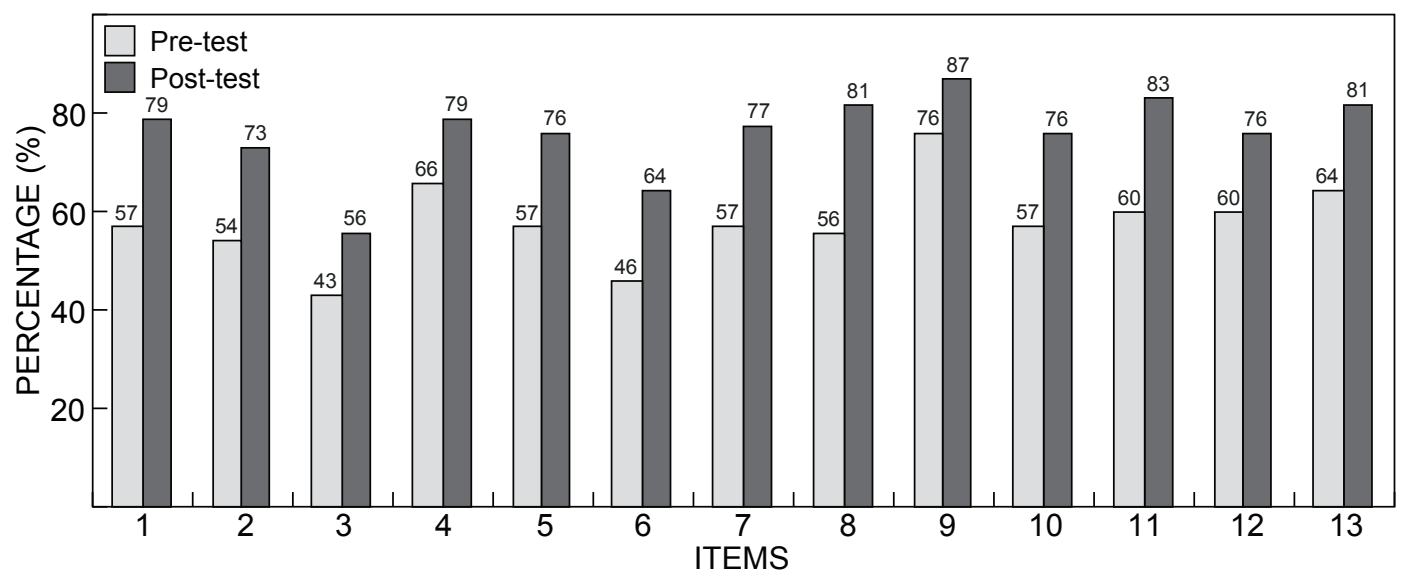

Figure 2: Comparison of pre- and post-test results per item

test that is suitable for the analysis of small samples, as in the present case. The test indicates the probability of a significant difference between pre- and post-test ratings, and is appropriate for comparing data from the same participants - in this case the pre- and post-tests written by each of the respondents who participated in the subject-specific intervention.

The improvement proves to be consistent across the three primary dimensions of the rating scale, viz.: 'Use of source materials', 'Structure and development', and 'Academic writing style'. Table 3 shows the subtotals for the three dimensions converted to percentages.

The results presented in Figure 2 should be interpreted against the probability values obtained from the Wilcoxon signed-rank test on the individual items. The hypothesis is that the intervention improved students' skills, resulting in higher ratings on their essays. A one-sided probability value ( $p$-value) is therefore reported.

Table 4 lists the $p$-values for each of the 13 items considered in the analysis. Calculated $p$-values less than 0.05 indicate that there is a significant improvement from the pre- to the post-test ratings awarded by Rater 1 at a $5 \%$ level of significance:

According to Table 4 the improvement between the pre- and post-test ratings is significant for all the items; with the exception of items 3 and 6 , which are significant at the $10 \%$ level. A larger sample might have resulted in significant improvement at the $5 \%$ level for these two questions as well.

Although the findings indicate that the intervention was successful in terms of the improvement of performance, the success of academic literacy interventions are equally dependent on students' experience, which are co-determinants of motivation and skills transfer. For this reason it was decided to survey the participants on their opinions.

\section{Opinion survey}

\section{Conceptual framework}

An opinion survey was conducted to measure students' attitudes regarding the various dimensions of a critical, genre-focused, subject-specific writing intervention. At the conclusion of the module all ten students who followed through from the pre-test to the post-test filled in a questionnaire comprising 29 statements. These statements operationalised typical features of critical genrefocused syllabi, viz.: 'Scaffolding', 'Social apprenticeship', 'Needs-driven' and 'Critical orientation', with the exception of 'Target-centredness'. This decision was motivated by the first author's conviction that second-year students are not yet equipped to judge the fulfilment of disciplinary requirements. Instead, 'Skills transfer' was added to prove/disprove the most important criticism against genre-focused approaches: that these approaches reverted back to the 'scientific approach' to 
Table 3: Improvement of students output between the pre- and the post-test

\begin{tabular}{lccc}
\hline Dimension & Mean: pre-test & Mean: post-test & Improvement \\
\hline $\begin{array}{l}\text { Use of source materials } \\
\text { (Items 1-3) }\end{array}$ & $51 \%$ & $69 \%$ & $18 \%$ \\
\hline $\begin{array}{l}\text { Structure and development } \\
\text { (Items 4-7) }\end{array}$ & $56 \%$ & $74 \%$ & $18 \%$ \\
$\begin{array}{l}\text { Academic writing style } \\
\text { (ttems 8-12) }\end{array}$ & $62 \%$ & $81 \%$ & $19 \%$ \\
\hline
\end{tabular}

Table 4: One-sided $p$-values of the pre- and post-test ratings for the 13 items, obtained from the Wilcoxon signed-rank test

\begin{tabular}{ll}
\hline Item & $p$-value \\
\hline 1 & 0.0062 \\
2 & 0.0105 \\
3 & 0.0742 \\
4 & 0.0429 \\
5 & 0.0019 \\
6 & 0.0859 \\
7 & 0.0039 \\
8 & 0.0019 \\
9 & 0.0468 \\
10 & 0.0039 \\
11 & 0.0039 \\
12 & 0.0312 \\
13 & 0.0078 \\
\hline
\end{tabular}

language teaching, fostered transmission pedagogy and cultivated passive learners (compare Prior, 1995). Table 5 explicates the construct that was operationalised in the questionnaire.

Students had to indicate their responses to the statements comprising the questionnaire (attached as Appendix A) on standard five-point Likert scales. The response options were 'strongly agree', 'agree', 'uncertain', 'disagree' and 'strongly disagree'. Thirteen of the 29 statements were phrased in a negative way, meaning that 'strongly agree' and 'agree' indicated a negative evaluation of the particular characteristic of the course, whereas 'strongly disagree' and 'disagree' indicated a positive evaluation. The scales for 13 of the statements (statements 1, 4, 5, 7, 13, 16, 19, 20 21, 23, 24,25 and 27) had to be reversed to enable correct interpretation of the responses. Unfortunately the theoretical support for the construct validity of the instrument could not be verified empirically using the standard reliability analysis (i.e. the calculation of Cronbach's alpha with a corresponding item-analysis), due to the small sample (ten respondents). Simple descriptive statistics were used to analyse the data, and for ease of interpretation the summaries were organised according to the four typical features of critical genre-focused syllabi, plus the additional feature of skills transfer, as explicated by the conceptual framework.

\section{Presentation and discussion of students' opinions}

The average rating was obtained for each student on each of the five dimensions of the construct. Figure 3 summarises the results. Even though some students rated some of the individual statements negatively, on average the responses to the statements comprising each dimension were predominantly positive. It had been expected that students would appreciate the scaffolding (Dimension 1), working together with peers with similar academic and professional interests (Dimension 2), and the overt emphasis on student needs (Dimension 3). These expectations were 
Table 5: Explication of the five dimensions of the construct underlying the opinion survey

\begin{tabular}{|c|c|}
\hline Dimensions & Description \\
\hline $\begin{array}{l}\text { 1. Staged and scaffolded teaching and } \\
\text { learning model }\end{array}$ & $\begin{array}{l}\text { Explicit pedagogical framework (visible pedagogy) } \\
\text { Modelling (using exemplars as model texts) } \\
\text { Gradual progress from maximal teacher-and peer-assistance to } \\
\text { complete independence } \\
\text { Explicit teaching of discourse structure } \\
\text { Explicit teaching of lexicogrammar }\end{array}$ \\
\hline 2. Purposeful social apprenticeship & $\begin{array}{l}\text { Aimed at attaining goals that are important to expert members } \\
\text { of the discourse community into which the student wishes to be } \\
\text { assimilated } \\
\text { Learning through actively engaging with authentic subject matter, } \\
\text { while being supervised by the master/lecturer, and assisted by } \\
\text { peers }\end{array}$ \\
\hline 3. Needs-driven syllabus & $\begin{array}{l}\text { Content and pedagogy are attuned to the wants, needs and skills } \\
\text { level of the learner. }\end{array}$ \\
\hline 4. Critical orientation & $\begin{array}{l}\text { Explicit knowledge of the conventions of valued academic genres } \\
\text { empowers students and heightens metacognitive awareness to } \\
\text { facilitate self-evaluation } \\
\text { Critical analysis of texts enables students to unveil ideology and } \\
\text { hidden agendas } \\
\text { Students are encouraged to challenge prescriptive genre } \\
\text { conventions }\end{array}$ \\
\hline 5. Skills transfer & $\begin{array}{l}\text { The principles of structure and language that are taught can be } \\
\text { transferred to other contexts and genres (therefore it cannot be } \\
\text { asserted that this approach stifles creativity or cultivates passive } \\
\text { learners) }\end{array}$ \\
\hline
\end{tabular}

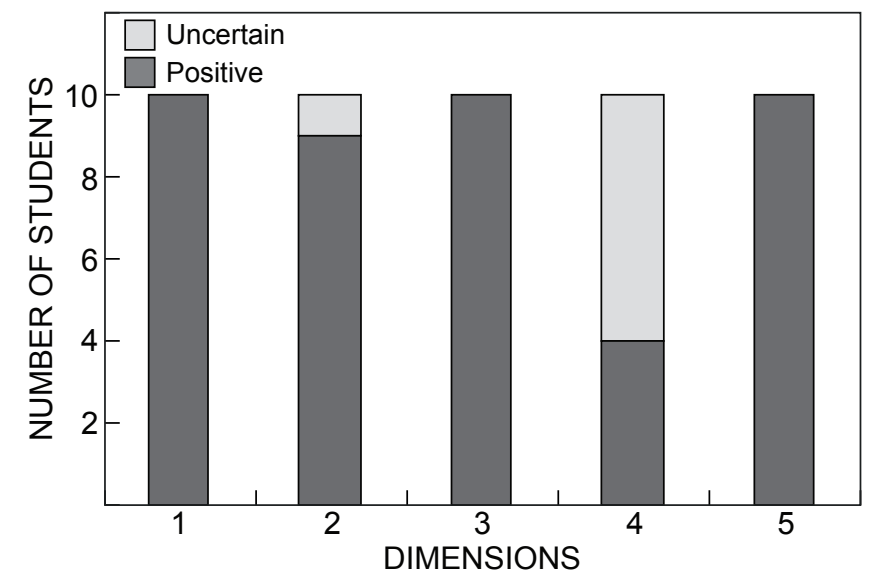

Figure 3: Students' opinions on the five dimensions of the construct ('positive' means 'favourably inclined towards the course regarding the concept in question')

largely fulfilled. Although approximately $5 \%$ of the students indicated that they were uncertain as to whether all their personal needs had been addressed (Dimension 2), 5\% uncertainty was not regarded to be a reason for concern. The overwhelming positive response to the statements 


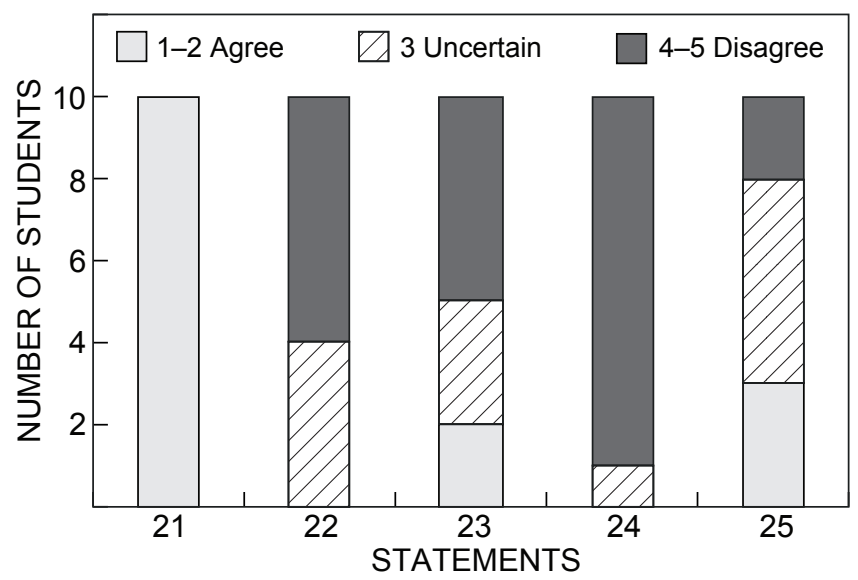

Figure 4: Responses to the concepts evaluated by statements 21-25 (= Dimension 4)

in Dimension 5 was a pleasant surprise because of the regular criticism that the genre approach fostered passive learning. The students clearly thought that the skills they had learned were transferable to other contexts.

Experience with course evaluations over 25 years had taught the first author that students were hesitant to admit that any university courses had taught them critical skills. The generally negative responses to the statements in Dimension $4(60 \%)$ were therefore not a complete surprise. However, it still called for further investigation. The original (unreversed) responses to the statements comprising Dimension 4 - summarised in terms of agreement, disagreement and uncertainty - are displayed in Figure 4. (The scales for Statements 23-25 were reversed for the statistical analysis to bring their polarity in line with that of Statements 21 and 22.)

The results indicated in Figure 4 can be interpreted and explained as follows:

Statement 21: 'It is empowering to know how to write in the genres valued by academics.' The statement was phrased positively; thus the graph indicates $100 \%$ positive evaluation of empowerment through genre knowledge.

Statement 22: 'If one of my academic lecturers says that it is forbidden to refer to myself ("I") in academic writing, I will take issue with him/her.' The statement was phrased positively; thus $60 \%$ expressed hesitance to challenge the authority of the lecturer. Possible explanations are that the students may have been unfamiliar with the phrase 'take issue with', or that second-year students do not yet have the self-confidence to challenge the authority of a subject-field lecturer.

Statement 23: 'One should accept the content of textbooks and academic articles as true.' The statement was phrased negatively; thus a third of the students believe that the authority of prescribed sources should not be questioned or challenged.

Statement 24: 'It is impossible to criticise one's own work.' The scale has a negative polarity; thus $90 \%$ of the students believe that self-reflection comprises an essential part of successful academic writing.

Statement 25: 'Empowerment in tertiary education means that students should be allowed to write as they speak.' The statement is phrased negatively; thus $80 \%$ of the respondents harbour a misconception regarding an important objective of the intervention. This misconception might have originated in erroneous interpretations of Communicative Language Teaching encountered at school level. Another possible explanation is that the learner-centredness and the rigorous scaffolding that underpinned the intervention might have created the impression of an accommodationist approach. 


\section{Conclusion}

Based on the statistical analysis of the pre- and post-test results it could be claimed that students' writing abilities improved significantly between the pre- and the post-test. Furthermore, it is highly probable that the intervention itself contributed to this improvement. The overall improvement was about equal on the three primary dimensions measured by the analytic pre- and post-test assessment: 'Handling of source materials' (18\%), 'Structure and development' (18\%) and 'Academic writing style' (19\%).

The results of two items - those concerning 'Stance and engagement' (Item 3) and 'Conclusion' (Item 6) - were disappointing, as reflected by the p-values which were only significant at the $10 \%$ level, and not at the $5 \%$ level. A larger sample is necessary to establish whether the improvement after intervention is indeed statistically significant.

According to the results of the attitude survey, students were generally very positive about the effect of the intervention on their academic writing abilities. They showed appreciation for all the 'signature' features of a genre-focused approach, and their responses seem to refute the criticism that genre approaches promote 'transmission pedagogy'. Issues that should be addressed overtly in future interventions are formality and precision in academic writing, and developing the self-confidence to challenge the authority of lecturers and lecturing materials when merited.

In conclusion it should be noted that the outcomes of this evaluation do not disprove the possible effectiveness of more generic writing interventions. To facilitate comparison, a similar intervention with a broader subject-field focus will have to be designed, administered and evaluated, using the same evaluation instruments, but preferably employing a larger sample.

Acknowledgements - We would like to thank our colleagues from the Department of Historical and Heritage Studies for their input before and during the subject-specific intervention, in particular Ms Karina Sevenhuysen for her advice and facilitation. Our sincere thanks also to Ms Jaqui Sommerville for her assistance with the statistical analyses.

\section{References}

Berkenkotter C \& Huckin TN. 1995. Genre Knowledge in Disciplinary Communication: Cognition/ Culture/Power. Hillsdale, NJ: Lawrence Erlbaum.

Bhatia VK. 1993. From description to explanation in language teaching. In Bhatia VK (ed.), Analysing genre: language use in professional settings. London/New York: Longman, pp 147-206.

Bhatia VK. 2004. Worlds of Written Discourse: A Genre-Based View. London: Continuum.

Biber D. 1988. Variation Across Speech and Language. Oxford: Oxford University Press.

Biber D. 2006. University Language: A Corpus-Based Study of Spoken and Written Registers. Amsterdam: John Benjamins.

Bonanno H \& Jones J. 2007. Measuring the Academic Skills of University Students (3rd edn). Sydney: University of Sydney.

Burke P. (ed.) 2001. New Perspectives on Historical Writing. Pennsylvania: Pennsylvania State University Press.

Carstens A. 2008a. Preferred genres and rhetorical modes in the humanities and social sciences. Language Matters 39(1): 49-65.

Carstens A. 2008b. A multidirectional model for tertiary-level disciplinary writing. Journal for Language Teaching 42(1): 81-97.

Carstens A. 2008c. Essay-writing module for second-year students of history. Per Linguam 28(2): 1-20.

Coffin C. 2003. Reconstruing the past: settlement or invasion? In Martin JR \& Wodak R (eds), Re/ reading the Past: Critical and Functional Perspectives on Time and Value. Amsterdam: John Benjamins, pp 219-246.

Coffin C. 2006. Historical Discourse: The Language of Time, Cause and Evaluation. London: Continuum.

Cope B \& Kalantzis M (eds) 1993. Powers of Literacy: A Genre Approach to Teaching Writing. London: Falmer Press. 
Cope B \& Kalantzis M. 2000. Introduction: Multiliteracies: the beginnings of ideas. In Cope B \& Kalantzis M (eds), Multiliteracies: Literacy Learning and the Design of Social Futures. London \& New York: Routledge, pp 3-8.

Department of Historical and Heritage Studies. 2006. Study Manual. Pretoria: University of Pretoria.

Eggins S, Wignell P \& Martin JR. 1993. The discourse of history: distancing the recoverable past. In Ghadessy M (ed.), Register Analysis: theory and Practice. London: Pinter, pp 75-109.

Evans RJ. 1997. In Defence of History. London: Granta Books.

Faigley L \& Hansen K. 1985. Learning to write in the social sciences. College Composition and Communication 36(2): 140-149.

Halliday MAK. 1978. Language as a Social Semiotic. The Social Interpretation of Language and Meaning. London: Edward Arnold.

Hewings A \& Hewings M. 2001. Approaches to the study of disciplinary variation in academic writing. In Hall DR \& Hewings A (eds), Innovation in English Language Teaching. London \& New York: Routledge, pp 71-83.

Hewings A. 2004. Developing discipline-specific writing: an analysis of undergraduate geography essays. In Ravelli LJ \& Ellis RA (eds), Analysing Academic Writing. London: Continuum, pp 131-152.

Hyland K. 2000. Disciplinary Discourses: Social Interactions in Academic Writing. Harlow: Longman.

Hyland K. 2003. Second Language Writing. New York: Cambridge University Press.

Hyland K. 2004. Genre and Second Language Writing. Ann Arbor: University of Michigan Press.

Hyland K. 2006. English for Academic Purposes. New York: Routledge Applied Linguistics.

Hyland K \& Bondi M (eds) 2007. Academic Discourse Across Disciplines. Frankfurt: Peter Lang.

Jones J. 2004. Learning to write in the disciplines: the application of systemic functional linguistic theory to the teaching and research of student writing. In Ravelli LJ \& Ellis RA (eds), Analysing Academic Writing. London: Continuum, pp 254-274.

Macken-Horarik M. 2002. 'Something to shoot for': a systemic functional approach to teaching genre in secondary school science. In Johns AM (ed.), Genre in the Classroom: Multiple Perspectives. London: Lawrence Erlbaum, pp 43-72.

Marius R \& Page ME. 2005. A short guide to writing about history ( $5^{\text {th }}$ edn). New York: Pearson Education.

Martin JR. 2003. Making history in re/reading the past. In Martin JR \& Wodak R (eds), Re/reading the Past: Critical and Functional Perspectives on Time and Value. Amsterdam: John Benjamins, pp 19-57.

Marwick A. 2001. The New Nature of History: Knowledge, Evidence, Language. Basingstoke, Hampshire: Palgrave.

Prior P. 1995. Redefining the task: an ethnographic examination of writing and response in graduate seminars. In Belcher D \& Braine G (eds), Academic Writing in a Second Language. Norwood, NJ: Ablex Publishing, pp 47-82.

Rael P. 2004. Reading, writing and researching history. A guide for college students. Available at http://academic.bowdoin.edu/WritingGuides/prael@ bowdoin.edu [Accessed 31 July 2007].

Rampolla ML. 2004. A Pocket Guide to Writing in History (4th edn). Boston, MA: Bedford/St. Martin's.

Rothery J. 1996. Making changes: developing an educational linguistics. In Hasan R \& Willimans G (eds), Literacy in Society. London: Longman, pp 86-123.

Saunders C. 1988. The Making of the South African Past: Major Historians on Race and Class. Cape Town: David Philip.

Schleppegrell M \& Achugar M. 2003. Learning language and learning history: a functional linguistics approach. TESOL Journal 12(2): 21-27.

Schleppegrell MJ, Achugar M \& Oteiza T. 2004. The grammar of history: enhancing contentbased instruction through a functional focus on language. TESOL Quarterly 38(1): 67-93.

Shafer RJ. 1980. A Guide to Historical Method. Belmont, CA: Wadsforth Publishing. 
Sharpe J. 2001. History from below. In Burke P (ed.), New Perspectives on Historical Writing (2 ${ }^{\text {nd }}$ edn). University Park, Pennsylvania: Pennsylvania State University Press, pp 25-42.

Smith K. 1988. The Changing Past: Trends in South African Historical Writing. Johannesburg: Southern Book Publishers.

Storey WK. 2004. Writing History: A Guide for Students (2nd edn). Oxford: Oxford University Press.

Tedick DJ. 1990. ESL writing assessment: subject-matter knowledge and its impact on performance. English for Specific Purposes 9: 123-143.

Tosh J. 2006. The pursuit of history. London/New York: Pearson/Longman.

Vygotsky LS. 1978. Mind in Society: The Development of Higher Psychological Processes. Cambridge, MA: Cambridge University Press.

Weideman AJ. 2007. Overlapping and divergent agendas: writing and applied linguistics research. In Van der Walt C (ed.), Living Through Languages: An African Tribute to René Dirven. Stellenbosch: African Sun Media, pp 147-163.

Weigle SC. 2002. Assessing Writing. Cambridge, UK: Cambridge University Press.

Williams TA, Sweeney DJD \& Anderson R. 2009. Contemporary Business Statistics. Oklahoma City: South-Western, pp 764-770. 


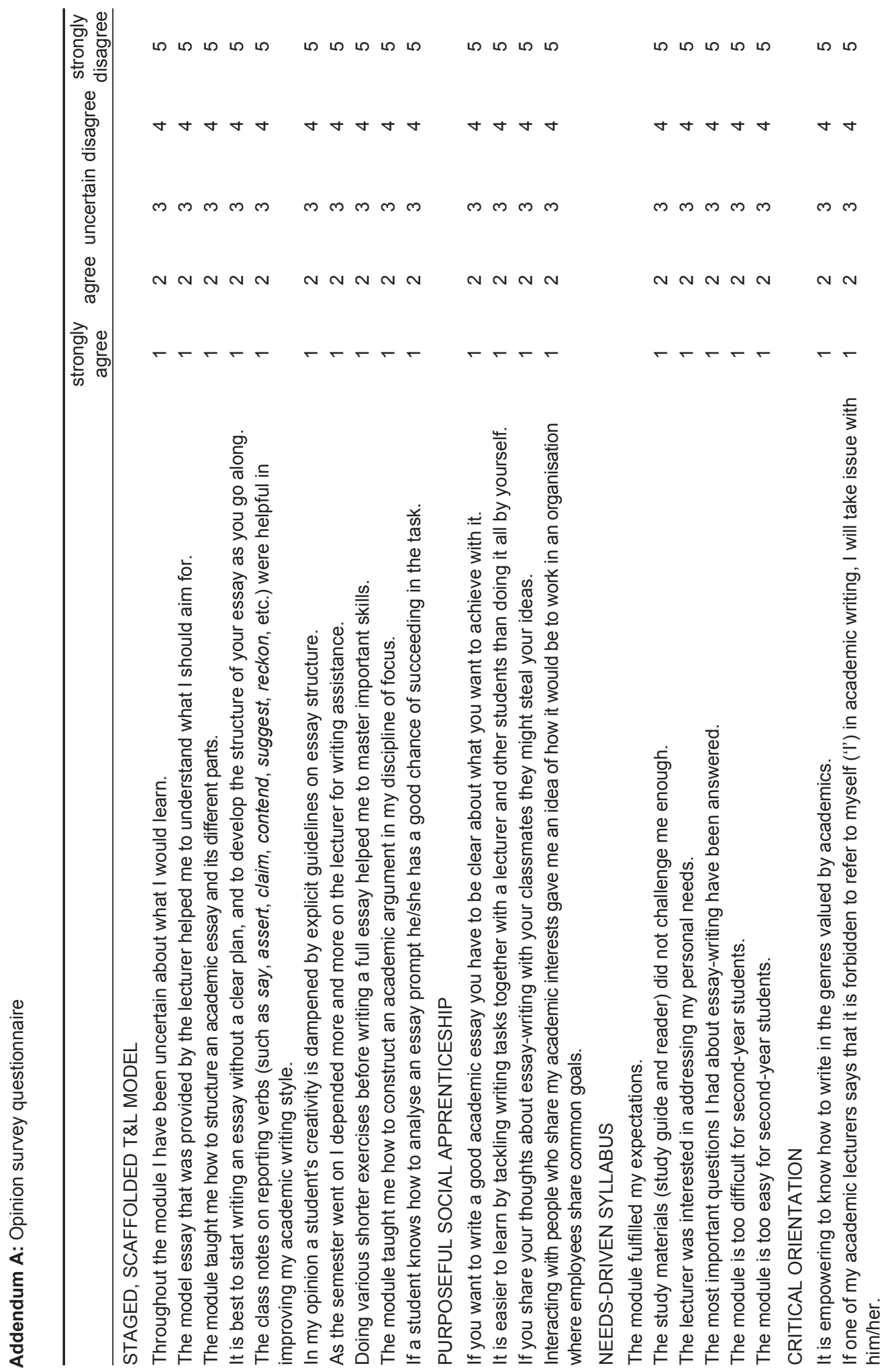






